Working Paper/Document de travail

2008-47

\title{
How Important Is Liquidity Risk for Sovereign Bond Risk Premia? Evidence from the London Stock Exchange
}

by Ron Alquist 
Bank of Canada Working Paper 2008-47

December 2008

\title{
How Important Is Liquidity Risk for Sovereign Bond Risk Premia? Evidence from the London Stock Exchange
}

\author{
by \\ Ron Alquist \\ International Economic Analysis Department \\ Bank of Canada \\ Ottawa, Ontario, Canada K1A 0G9 \\ ralquist@bankofcanada.ca
}

Bank of Canada working papers are theoretical or empirical works-in-progress on subjects in economics and finance. The views expressed in this paper are those of the author.

No responsibility for them should be attributed to the Bank of Canada. 


\section{Acknowledgements}

I would like to thank my colleagues in the International Department at the Bank of Canada, seminar participants at the University of Saskatchewan, Laura Beny, Ben Chabot, Lutz Kilian, Linda Tesar, Marc Weidenmier, and Kathy Yuan for their comments. Brian DePratto, Maggie Jim, and Golbahar Kazemian provided first-rate research assistance. 


\begin{abstract}
This paper uses the framework of arbitrage-pricing theory to study the relationship between liquidity risk and sovereign bond risk premia. The London Stock Exchange in the late $19^{\text {th }}$ century is an ideal laboratory in which to test the proposition that liquidity risk affects the price of sovereign debt. This period was the last time that the debt of a heterogeneous set of countries was traded in a centralized location and that a sufficiently long time series of observable bond prices are available to conduct asset-pricing tests. Empirical analysis of these data establishes three new results. First, sovereign bonds with wide bid-ask spreads earn 3-4\% more per year than bonds with narrow bid-ask spreads, and the difference is reflected in greater sensitivity to innovations in market liquidity. Second, small sovereign bonds, as measured by market value, earn 1.8-3.5\% more per year than large sovereign bonds, and the difference is also reflected in their exposure to innovations in market liquidity. Third, market liquidity is a state variable important for pricing the cross-section of sovereign bonds. This paper thus provides estimates of the quantitative importance of liquidity risk as a determinant of the sovereign risk premium and underscores the significance of market liquidity as a nondiversifiable risk.
\end{abstract}

JEL classification: F21, F34, F36, G12, G15

Bank classification: Financial markets; International topics

\title{
Résumé
}

Dans cette étude, l'auteur examine le lien entre le risque de liquidité et les primes de risque des obligations souveraines à l'aide de la théorie de l'arbitrage appliquée à l'évaluation des actifs. La Bourse de Londres à la fin du XIX ${ }^{\mathrm{e}}$ siècle constitue un laboratoire idéal pour mettre à l'épreuve l'hypothèse selon laquelle le risque de liquidité influe sur le prix des obligations souveraines. Cette époque est en effet la dernière au cours de laquelle la négociation des titres de dette d'un ensemble hétérogène d'États a été centralisée dans un même lieu et elle fournit des données qui permettent d'observer les prix des obligations sur une période suffisamment longue pour effectuer des tests d'évaluation des actifs. Une analyse empirique de ces données débouche sur trois nouveaux résultats. Premièrement, les obligations souveraines qui présentent de larges écarts entre les cours acheteur et vendeur rapportent 3 à $4 \%$ de plus par an que celles pour lesquelles ces écarts sont faibles, et cette différence se traduit par une sensibilité accrue aux variations inattendues de la liquidité du marché. Deuxièmement, les petites obligations souveraines (d'après la valeur de marché) affichent des rendements annuels supérieurs de 1,8 à 3,5\% à ceux des obligations souveraines de grande taille; cette différence se répercute également sur la sensibilité 
du rendement de ces titres aux fluctuations imprévues de la liquidité. Enfin, la liquidité du marché s'avère une variable d'état importante aux fins de l'évaluation d'un échantillon transversal d'obligations souveraines. L'étude fournit des estimations quantitatives de l'influence du risque de liquidité sur l'établissement de la prime de risque souverain et met en évidence l'importance de la liquidité du marché en tant que risque non diversifiable.

Classification JEL : F21, F34, F36, G12, G15

Classification de la Banque : Marchés financiers; Questions internationales 


\section{Introduction}

Liquidity risk - the risk that the price of a security will decline when the market as a whole becomes illiquid - is important for understanding the sovereign bond risk. Liquidity describes the ease with which an investor can anonymously trade large quantities of a security quickly, at low cost, and without altering the security's price. Understanding the relationship between a security's return and market liquidity is especially important during financial crises when market liquidity becomes scarce. During such crises market participants tend to value liquidity more highly and shift into more liquid sovereign bonds in so-called "flights to liquidity". 1 This reasoning suggests that the price of more liquid bonds will be less sensitive to abrupt changes in market liquidity during periods of financial stress.

Flights to liquidity are increasingly common in international financial markets. In the fall of 1998 the price of US Treasuries increased sharply relative to less liquid financial instruments, including non-US sovereign bonds, in response to the Russian default, the failure of Long-Term Capital Management, and pervasive financial turbulence. More recently, the turmoil associated with the subprime mortgage crisis caused a systemic liquidity crisis in international financial markets and induced investors to shift into more liquid US and European sovereign bonds. In mid-September 2008 yields on US Treasuries had reached their lowest level since January 1941 (Guha, Mackenzie, and Tett, September 17, 2008). At the beginning of 2008 investors also moved into liquid German government bonds at the expense of less-liquid debt instruments:

"One reason for the spread [between eurozone government bond yields] widening is the existence of a liquid futures market in Germany, which traders use to hedge investments and which has created a natural demand for German Bunds over other eurozone debt, particularly during recent months of market uncertainty (Chung, February 28, 2008)."

This evidence suggests that sovereign debt instruments may carry different sensitivities to liquidity risk, but it does not conclusively establish the quantitative importance of market liquidity as a nondiversifiable risk. To the extent that economists have found a role for liquidity risk in the market for international debt, they have done so for small samples of countries and for

\footnotetext{
${ }^{1}$ A flight to liquidity is a type of flight to quality, where the quality an investor values is the ease with which he can convert the security into cash during periods of market distress.
} 
the period since the late 1990s due to limitations on data availability (see, for example, Dittmar and Yuan 2008).

The London Stock Exchange prior to the First World War is an ideal laboratory for directly confronting the issue of liquidity risk and sovereign bond risk premia. A centralized market for trading international debt is a relatively recent development and long time series of transaction data suitable for conducting asset-pricing tests are unavailable. In contrast, observable bid-ask spreads denominated in a common currency for a heterogeneous set of sovereign borrowers are available from the early 1870s until 1907. This era also spans several complete cycles of international borrowing, ensuring substantial time-series variation in the behavior of market liquidity and sovereign risk premia. The availability of transaction data from the London sovereign debt market therefore offers a unique opportunity to study the relationship between liquidity risk and sovereign risk premia. In light of the recent evidence that liquidity risk seems to be a nondiversifiable risk, this paper uses the London data to establish the enduring economic importance of liquidity risk in international debt markets and to offer estimates of the size of the liquidity premium that provide a benchmark for understanding its role in today's international debt market. $^{2}$

The paper’s results are highly informative. First, sovereign bonds with wide bid-ask spreads earn 3-4\% more per year than sovereign bond with narrow bid-ask spread, and this difference tends to be reflected in their exposure to unexpected changes in market liquidity. Second, small sovereign bonds, as measured by market value, earn 1.8-2.5\% more per year than large bonds, and this difference is reflected in their exposure to unexpected changes in market liquidity. Third, there is strong evidence that market liquidity is a state variable important for pricing the cross-section of sovereign bonds. The data reject the null hypothesis that including market liquidity as a traded factor does not improve the model's fit, suggesting an independent role for liquidity risk as a determinant of the price of sovereign debt. The contribution of liquidity risk to the overall sovereign risk premium is about the same size as the contribution of business-cycle risk. This paper therefore establishes the economic importance of market liquidity as a nondiversifiable risk in international financial markets and situates recent flights to liquidity within a broader perspective.

\footnotetext{
${ }^{2}$ This paper thus uses the London Stock Exchange as a laboratory to study liquidity risk and does not take up the issue of the parallels between that era of extensive international financial integration and today's. On this topic, see Mauro, Sussman, and Yafeh (2002), Taylor (2002), and Bordo and Murshid (2006).
} 
Section 2 discusses the features of the $19^{\text {th }}$ century sovereign debt that make it an excellent testing ground for studying the relationship between liquidity risk and sovereign bond risk premia. Section 3 reviews how arbitrage-pricing theory casts light on the relationship between nondiversifiable liquidity risk and sovereign bond risk premia. Section 4 describes the data, the construction of the market liquidity measure, and the time-series features of this indicator. Section 5 presents evidence on the economic importance and statistical significance of the liquidity premium embedded in sovereign bond prices. Section 6 concludes.

\section{The London Stock Exchange as a Laboratory}

This paper uses sovereign bond price data from the London Stock Exchange because it is a rich laboratory for studying the link between liquidity risk and the price of sovereign debt. These data comprise the entire population of quoted sovereign bond prices available on the London Stock Exchange between 1871 and 1907 and consist of bonds issued by 49 countries.

Continuously observable bid and ask prices are available for almost 40 years and, in light of London's significance as a financial center during that period, the sample represents a substantial fraction of the entire universe of bonds traded in the world during that time (Michie 2006). This period encompasses the peaks and troughs of several international business cycles, including the depression that began in 1873; financial crises that affected the major sovereign borrowers; and at least three lending booms in the London sovereign debt market - one in the mid-1870s, one in the mid-1880s, and one in the decade before the First World War (Suter 1990). The cross-section of issuers is sufficiently diverse to guarantee dispersion in the factor sensitivities across test portfolios, which aids in the cross-sectional identification of the assetpricing model, and the time series of bond prices are long enough to conduct asset-pricing tests with statistical power.

It may seem surprising that sovereign bond price data for the contemporary era are not more widely available, but there were no centralized markets for trading such debt until recently. ${ }^{3}$ The secondary market for sovereign debt is an over-the-counter market in which the bond's price is negotiated privately between the buyer and the seller in what can be a complex

\footnotetext{
${ }^{3}$ Datastream provides bond price data from the mid-1990s. Bloomberg has price data for some bonds since 1987, but bid and ask prices are available for only a small set of countries and for shorter time periods, and volume data are unavailable. The data provider Markit does not have transaction data from the sovereign bond market, although a representative from the firm suggested that Goldman Sachs or Citigroup may have time series of proprietary data from the over-the-counter market.
} 
and time-consuming process. ${ }^{4}$ The market's opacity makes it challenging to construct transaction-based indicators of liquidity that are comparable across countries. For example, the authors of a Bank for International Settlements (BIS) study of government bond market liquidity had problems comparing liquidity measures among the G10:

"Many of the individual papers [about government bond market liquidity] contained in this report attempt to measure market liquidity taking into account the...dimensions [of liquidity] listed above. The data actually used to measure liquidity, however, vary greatly across the different papers, not least because of differences in the underlying market structures (Bank for International Settlements 1999, p. 13).”

Such cross-country differences in how transactions in the government bond market are negotiated made it difficult for the authors to compute comparable bid-ask spreads. Consistent bid and ask prices data were unavailable and each country's central bank provided estimates of the bid-ask spread (Inoue 1999, p. 4).

This lack of transaction data prevents economists from studying the relationship between liquidity risk and sovereign bond risk premia for a broad cross section of countries over a long period of time. Papers that examine this relationship across countries are limited to drawing inferences for narrow cross sections of countries in the period since the mid 1990s (see, for example, Dittmar and Yuan 2008). Papers that study bond-market liquidity for individual countries using long time series of transaction data must focus on those countries that have highly articulated financial markets, restricting the applicability of their conclusions (see, for example, Takagi 1987; and Fleming 2002).

Since the mid-1990s technological developments have improved the transparency of the secondary market for sovereign debt and facilitated the dissemination of transaction data. Prior to these recent developments, however, there was no mechanism for ensuring that these transaction data were widely disseminated. Because sovereign debt in London was traded in a single, centralized market, these price data enable the econometric identification of the relationship between liquidity risk and sovereign risk premia without having to control for

\footnotetext{
${ }^{4}$ This argument applies with greater force to developing countries. Although the Brady Plan created a relatively liquid market in developing-country debt starting in early 1990, the secondary market for such bonds was thin until the mid-1990s and the pricing data commensurately unreliable (Stone 1991). To the extent that transaction data for these bonds have become available since then, price data are not publicly available because the market for such instruments is an over-the-counter market as well (see, for example, Cumby and Pastine 2001).
} 
different levels of liquidity in markets that are geographically segmented or financial markets that are impartially integrated.

The London data therefore offer a real advantage over today's data for directly testing the proposition that liquidity risk is an important determinant of sovereign risk premia. These advantages permit us to study the quantitative importance of the liquidity premium using methods that decompose the sovereign risk premium into its constituent components, including the component due to liquidity risk, as discussed in Section 3. Such methods can provide quantitative estimates of the liquidity premium that shed new light on the casual evidence about flights to liquidity in today's international financial markets.

\section{Arbitrage-Pricing Theory, Multifactor Models, and Sovereign Bond Risk Premia}

Recent evidence from the US Treasury market suggests a role for liquidity in the pricing of this debt. US Treasuries trade at higher prices than other debt instruments also guaranteed by the US government, and the spread between these two prices is correlated with different measures of changes in market sentiment (Longstaff 2004). Such evidence only indirectly supports the hypothesis that liquidity affects sovereign bond prices, however. If investors are willing to pay for liquidity in the sovereign bond market, it follows that they would have to be compensated for bearing the risk associated with illiquidity.

Arbitrage-pricing theory provides a natural framework for systematically evaluating the effect of liquidity as a nondiversifiable risk on sovereign risk premia. The theory predicts that a security’s risk premium is proportional to its sensitivity to unexpected changes in a set of nondiversifiable risks (Ross 1976; and Huberman 1982). It postulates that security returns are generated by their exposure to a set of common risks:

$$
r_{i}=\bar{r}_{i}+\sum_{k=1}^{K} \beta_{k i} f_{k}+\varepsilon_{i}
$$

where $\bar{r}_{i}$ is the expected return on security $i=1, \ldots, N ; f_{k}=F_{k}-E\left[F_{k}\right]$ is the unanticipated change in the common, nondiversifiable risk factor $F_{k}$ that drives security returns; $\beta_{k i}$ is the sensitivity of the returns of security $i$ to unanticipated changes in the nondiversifiable risk factor $k$; and $\varepsilon_{i}$ is the idiosyncratic component in the returns of security $i$. 
The assumptions that investors are utility-maximizing, risk-averse, and trade in a frictionless market imply that one can express the expected risk premium $\overline{r_{i}}-r_{f}$ of a security $i$ as a linear function of its exposure to nondiversifiable risks

$$
\overline{r_{i}}-r_{f}=\sum_{k=1}^{K} \beta_{k i} \lambda_{k}
$$

where $r_{f}$ is the risk-free rate of interest; $\lambda_{k}=\bar{r}_{k}-r_{f}$ is the expected risk premium associated with the $k$ th nondiversifiable risk; and $\bar{r}_{k}$ is the return on the factor-mimicking portfolio $p_{k}$ that has unit risk on the $k$ th nondiversifiable factor $\beta_{p_{k}}=1$. The factor-mimicking portfolio captures the marginal returns associated with unit exposure to the nondiversifiable risk. For example, one can construct a liquidity-mimicking factor consisting of a leveraged portfolio that is long the least-liquid bonds and short the most-liquid bonds. This portfolio captures the realized return per unit of liquidity risk associated with the least liquid bonds. ${ }^{5}$

Arbitrage-pricing theory does not identify the particular set of nondiversifiable risks that influence returns, but asset-pricing models that incorporate market liquidity as a state variable conform to the theory's logic (Acharya and Pedersen 2005). Such models provide a rationale for incorporating market liquidity as a nondiversifiable risk into a multifactor model and impose testable restrictions on the relationship between innovations in market liquidity and security returns. These models predict that securities carry different exposures to unanticipated changes in market liquidity. Risk-averse investors demand a premium for holding securities whose payoffs also covary positively with these changes in market liquidity. A security's return is linearly related to its sensitivity to unexpected changes in market liquidity in the same way that the consumption-based capital asset pricing model predicts a security's return is linearly related to its sensitivity to unexpected changes in macroeconomic state variables (Chen, Roll, and Ross 1986). Studying liquidity risk and sovereign risk premia in such a multifactor framework is an intuitive extension of the underlying theory.

\footnotetext{
${ }^{5}$ Arbitrage-pricing theory offers a rationale for using such mimicking portfolios to capture the underlying nondiversifiable risks. In the absence of estimation error and with an infinite amount of data, a multifactor model is a linear recombination of the underlying nondiversifiable risk factors (Connor 1984). The returns associated with the factor-mimicking portfolio can replicate the time-series behavior of the state variables that drive security returns. Such strong assumptions do not apply in practice, but this argument offers a reason for why such a factor model is a plausible proxy for nondiversifiable risks.
} 


\section{Data}

The quality of the data set that this paper uses is hard to match. It consists of the closing bid and ask prices as well as the coupon payments for all of the sovereign bonds traded on the London Stock Exchange between 1866 and 1907. This data set contains 213 bonds issued by 38 countries and 110 bonds issued by 11 British colonies. The prices are sampled every 28 days from the official quotation list published in the Money Market Review between 1866 and 1907, when such detailed price quotations ceased to be available, and were supplemented with quotations from the Times of London and the Economist. The number of sovereign bond prices quoted in the Money Market Review does not exceed four until late 1870 and there are fewer than 10 price quotations until December 1870, after which the cross section of bonds grows very rapidly. This paper therefore uses the price data starting from January $1871 .^{6}$

\subsection{Measuring Sovereign Bond Risk Premia}

Using arbitrage pricing theory to study the relationship between liquidity risk and sovereign bond risk premia requires casting the problem in terms of holding-period returns rather than yields, but since prices rather than yields were quoted on the London Exchange, thinking about the problem in this way is quite natural. The net holding-period return $r_{t+1}$ is

$$
E_{t}\left[\frac{P_{t+1}+C_{t+1}}{P_{t}}\right]=1+r_{t+1} .
$$

where $P_{t+1}$ denotes the price of the sovereign bond at $t+1$; and $C_{t+1}$ denotes the coupon payment, if any, at $t+1$. The price $P_{t+1}$ is computed as the midpoint between the bid and ask prices. $^{7}$

If financial markets are efficient, the ex post return is the expected return plus an independent mean zero random error term $r_{t+1}=E_{t}\left[r_{t+1}\right]+\varepsilon_{t+1}$. The sample average of holdingperiod returns converges to its expected value and average ex post holding-period returns are a

\footnotetext{
${ }^{6}$ Appendix 1 contains more detail about the data set.

${ }^{7}$ Although using the midpoint to compute returns is standard, they tend to be larger than they would be if one computed monthly returns using the change from the ask price to the bid price. On the other hand, the ask-to-bid return assumes that the investor buys the security at the beginning of the month, sells it at the end of the month, and purchases it again at the beginning of the subsequent month. A bid-ask spread of $1 \%$ per month would imply transaction costs of $12 \%$ per year, which are large by any standard. In contrast, using the midpoint is consistent with the fact that a large number of trades take place strictly within the bid-ask spread and that the midpoint is a good proxy for the price at which transactions actually occur.
} 
good proxy for the unobservable expected returns. They embed information about the bond's duration and capture the time-series variation in the opportunity cost of borrowing and lending. Changes in the bond's price are thus good indicators of changing expectations about the risk associated with holding such debt. Other measures of the returns of sovereign debt such as the coupon yield do not capture the time-series variation in capital gains and losses associated with changes in the bond's price. The coupon yield ignores information about shifts in expectations embedded in such price changes.

\subsection{Market Liquidity}

There is no strong consensus which empirical measure of liquidity is best. Different measures of liquidity are often used to capture particular dimensions of liquidity and depend on the question that is being asked. For example, measures that rely on the volume of transactions are indicators of how broad the market is - that is, the extent to which the market is able to absorb numerous orders without large changes in the transaction price. Recent research indicates that there is a common component among different measures of liquidity, which in turn suggests that one can view each individual measure of liquidity as an approximation to the underlying liquidity factor (Korajczyk and Sadka 2008).

This study constructs a measure of liquidity based on the percent bid-ask spread, the difference between the prices at which an investor is able to buy and sell a security relative to the midpoint of these two prices. The bid-ask spread thus quantifies the cost associated with executing a single trade of a particular size and provides a direct measure of the transaction costs associated with trading.

The economic rationale for using the bid-ask spread to measure liquidity relies upon models in which market makers set these spreads to protect themselves against traders who possess superior information about the security’s fundamental value. Since the market maker cannot distinguish between traders who are informed and those who are not, the bid-ask spread for a security emerges as the market maker's compensation for the costs of this adverse selection problem (Copeland and Galai 1983; and Glosten and Milgrom 1985). It is indicative of the amount of asymmetric information associated with each security and the market liquidity index based on each individual security's spread measures the total amount of asymmetric information in the market. During periods when there is greater asymmetric information about the value of 
individual securities, this index should widen. There is empirical evidence that bid-ask spreads do widen during periods of market turbulence (Chordia, Sarkar, and Subrahmanyam 2005).

The index of market liquidity is constructed from the average of bid-ask spreads across sovereign bonds at a given point in time. The bid and ask prices span January 1871 to December 1907, yielding 482 time-series observations. ${ }^{8}$ The bid-ask spread for bond $i$ is:

$$
S_{i t}=\frac{P_{i t}^{a}-P_{i t}^{b}}{0.5\left(P_{i t}^{a}+P_{i t}^{b}\right)}
$$

where $P_{i t}^{a}$ is the ask price of the bond; and $P_{i t}^{b}$ is the bid price of the bond. The equally weighted bid-ask spread index for the entire market at a point in time is an indicator of market liquidity:

$$
L_{t}=N_{t}^{-1} \sum_{i=1}^{N_{t}} S_{i t}
$$

where $N_{t}$ is the number of bonds trading in period $t .{ }^{9} N_{t}$ is a function of time because the number of sovereign bonds traded on the London exchange grew over the sample period.

To capture the time-series variation in liquidity, the unexpected change in market liquidity between $t-1$ and $t$ is defined as:

$$
\Delta L_{t} \equiv L_{t}-E_{t-1}\left[L_{t}\right]
$$

That is, the innovation in market liquidity is the difference between current market liquidity and expected market liquidity. Let us postulate that $E_{t-1}\left[L_{t}\right]=L_{t-2}$ :

$$
\Delta L_{t}=L_{t}-L_{t-2}
$$

This measure is an ex ante indicator of unexpected changes in market liquidity because it postulates that expectations are formed prior to period $t-1$. It does not use information that would help to predict excess returns of sovereign bonds in period $t$, which are a function of the prices at $t-1$.

\footnotetext{
${ }^{8}$ There are 482 rather than 481 observations because there were 14 rather than the usual 13 issues of the Money Market Review published in 1897.

${ }^{9}$ With the market values of each bond in a particular period, one could construct a value-weighted index of bid-ask spreads. A value-weighted portfolio would assign weights to each bid-ask spread based upon the market value of the shares outstanding. For example, if the market value of Argentine bonds were ten times the value of Danish bonds, Argentina would receive ten times the weight of Denmark. The advantage of using the equally weighted bidask spread rather than the value-weighted spread as a measure of market liquidity is that doing so ensures the index is not skewed toward bonds with large market capitalizations, which tend to be immune to decreases in market liquidity. The equally weighted index is a broader measure of market liquidity than one that assigns larger, more liquid bonds a greater weight.
} 


\subsection{Time-Series Features of Bond Market Liquidity}

Table 1 summarizes the time-series features of market liquidity in the London sovereign bond market between 1871 and 1907. The first column shows the properties of the level series. The average market liquidity is about $2.4 \%$, and it is statistically different from zero. The range between the minimum and maximum values for market bond liquidity indicates the bid-ask spread lies between about 1.5 and 4.5\%. To put these values into perspective, the London bidask spreads are wider than the spreads in the secondary market for Japanese government bonds during the first half of the 1980s (Takagi 1987) or the bid-ask spreads in the market for US Treasury bills during the second half of the 1990s (Fleming 2002). In both markets the bid-ask spreads are smaller than $0.5 \%$ and most were smaller than $0.10 \%$. These differences can be explained by Japanese and US government bonds serving as international benchmarks and being the largest and most liquid in the world. At around 0.4\%, the bid-ask spread on Brady bonds is also smaller than the average London spread, although this comparison is inappropriate because Brady bonds are collateralized by US Treasury bonds. The London bid-ask spreads are closer in size to those associated with the non-Brady sovereign debt issued by emerging markets. For a sample of 8 countries, Dittmar and Yuan (2008) report average bid-ask spreads from 1996 to 2000 that range between $0.671 \%$ for Argentina and $1.771 \%$ for Venezuela.

The estimate of market liquidity is persistent. The sum of the autoregressive coefficients for this indicator is 0.93 , which is consistent with the magnitude documented by studies of the equity market in the current period (Korajczyk and Sadka 2008). Figure 1 provides visual evidence that this measure of market liquidity is persistent. The second column in Table 1 shows the properties of the change in the level of the bid-ask spread in percentage points. One cannot reject the null hypothesis that the mean of the series is zero. The differenced series is not persistent and appears stationary around a mean of zero.

Figures 2 and 3 provide visual evidence that the level and the change in market liquidity identify periods in which asymmetric information increased. These two figures plot the series and the dates associated with selected sovereign defaults during this period. As the figures illustrate, bid-ask spreads tend to be wide during periods when sovereign borrowers default on their foreign debts and these defaults are also associated with sharp increases in the spread. For example, the largest spike in the plot during 1875-76 is associated with the Ottoman Empire's 
default in October 1875 and Egypt's default in April 1876, two of the largest borrowers in the sovereign debt market during that period. The market-wide bid-ask spread also widened in anticipation of the Argentine default in April 1890, which precipitated the Baring crisis in November of that year, and the Brazilian default in June 1898. Although the market-wide bidask spread did not widen in anticipation of Greece’s default in December 1893, it did widen in the month of the actual default. Inspecting Figure 2 reveals that the market was relatively liquid in the 1870s, the mid-1880s, and between 1900 and 1907, which corresponds to the foreign lending booms in the London debt market. This indicator's time-series behavior thus broadly captures movements in market liquidity conditions.

\section{Empirical Evidence}

The regressions include: (1) the value-weighted market index of foreign bond returns, denoted $r_{M t}$, to capture the time-series variation of business-cycle risk common to all foreign sovereign bonds (Ilmanen 1995; and Barr and Priestley 2004); (2) the returns of the British consol to capture changes in British interest rates, denoted as $r_{C t}$, because the price of sovereign debt can reflect the return on alternative investments, as captured by the world interest rate (Uribe and Yue 2006); and (3) the portfolio $I M L_{t}$ that mimics the returns of a leveraged portfolio that is long $£ 1$ in the least liquid sovereign bonds and short $£ 1$ in the most liquid sovereign bonds. $I M L_{t}$ is defined as

$$
I M L_{t} \equiv r_{I L t}-r_{L t}
$$

where $r_{I L t}$ are the returns of the portfolio of the least-liquid sovereign bonds; and $r_{L t}$ are the returns of the portfolio of the most-liquid sovereign bonds. ${ }^{10}$ This portfolio captures the marginal returns associated with taking a position exposed to the risks faced by holding illiquid debt.

Sections 5.1 and 5.2 report the results from the time-series regression

$$
r_{i t}-r_{f t}=a_{i}+b_{M i}\left(r_{M t}-r_{f t}\right)+b_{C i}\left(r_{C t}-r_{f t}\right)+b_{L i} \Delta L_{t}+\varepsilon_{i t}
$$

\footnotetext{
${ }^{10}$ Starting in January 1871, each month the sorting procedure assigns the returns of each sovereign bond to one of ten portfolios based on the size of each bond's ex ante bid-ask spread. The liquidity-mimicking factor is the difference between the returns of the least liquid portfolio and the most liquid portfolio.
} 
for each of $i=1, \ldots, 10$ test portfolios of sovereign bonds sorted by the ex ante bid-ask spread (Section 5.1) and the ex ante market values (Section 5.2). $r_{i t}$ is the return on portfolio $i ; r_{f t}$ is the risk-free rate, the London banker bill rate; $a_{i}$ is the portfolio-specific risk premium and reflects the risk associated with holding portfolio $i ; b_{M i}$ is the sensitivity of test portfolio $i$ with respect to the market portfolio of sovereign bonds; $r_{M t}$ is the return of the market portfolio of sovereign bonds, weighted by value; $b_{C i}$ is the sensitivity of test portfolio $i$ with respect to the British consol index; $r_{C t}$ is the return of the British consol; $b_{L i}$ is the sensitivity of test portfolio $i$ with respect to the unexpected change in market liquidity; and $\Delta L_{t}$ is the unexpected change in liquidity in the sovereign bond market, constructed according to equation (6).

The point of estimating this equation for test portfolios sorted by these observable characteristics is to assess if doing so differentially exposes the test portfolios to the risk associated with unanticipated changes in liquidity, as measured by $b_{L i}$. As the evidence shows, sorting on either the bid-ask spread or the market value introduces dispersion in the factor sensitivities of the test portfolios. Less liquid sovereign bonds and smaller sovereign bonds tend to earn higher excess returns on a risk-adjusted basis and to be more exposed to liquidity risk.

Section 5.3 tests if liquidity is a priced state variable. Using generalized method of moments (GMM), one can estimate the risk premia based on the three-factor model

$$
\overline{r_{i}}-r_{f}=\beta_{M i} \lambda_{M}+\beta_{C i} \lambda_{C}+\beta_{I M L i} \lambda_{I M L}
$$

for $i=1, \ldots, 10$ test portfolios of sovereign bonds. In equation (8), $\overline{r_{i}}$ is the expected return of portfolio $i ; r_{f}$ is the risk-free rate, the London banker bill rate; $\beta_{M i}$ is the sensitivity of test portfolio $i$ with respect to the market portfolio of sovereign bonds; $\lambda_{M}=\bar{r}_{M}-r_{f}$ is the expected risk premium associated with the market portfolio of foreign sovereign bonds; $\beta_{C i}$ is the sensitivity of test portfolio $i$ with respect to the British consol index; $\lambda_{C}=\bar{r}_{C}-r_{f}$ is the expected risk premium associated with the British consol index; $\beta_{I M L i}$ is the sensitivity of test portfolio $i$ with respect to the liquidity-mimicking factor $I M L_{t}$; and $\lambda_{I M L}=\bar{r}_{I M L}-r_{f}$ is the expected risk premium associated with the liquidity-mimicking factor $I M L_{t}$. 
The point of estimating equation (8) is to assess the ability of the liquidity premium to explain cross-sectional differences in sovereign risk premia using the $D$-test (Newey and West 1987b). The null hypothesis is that the liquidity factor is not independently priced. Put differently, the hypothesis test amounts to testing whether including the foreign sovereign bond portfolio and the British consol index prices the test portfolios so well that one can ignore the return of the liquidity factor. As the evidence indicates, the data reject this hypothesis, which suggests that liquidity is a state variable important for pricing sovereign bonds.

\subsection{Are Less Liquid Bonds More Sensitive to Liquidity Innovations?}

Tables 2 and 3 report the results for equation (7). Table 2 does not include the unexpected change in market liquidity $\Delta L_{t}$ as an independent variable whereas Table 3 does include it. The results in the first row of Table 3 show that, unconditionally, the portfolio with the least liquid sovereign bonds earns, on average, an annualized excess return of 5.10\% whereas the portfolio with the most liquid bonds earns, on average, an annualized excess return of $2.48 \%$. Less liquid sovereign bonds command a higher return. Controlling for differences in business-cycle risk and interest-rate risk, the returns from the portfolio of illiquid sovereign bonds are larger than the returns from the portfolio of liquid bonds. The last column in Table 2 shows that a strategy of investing $£ 1$ in the least liquid sovereign bond portfolio and selling $£ 1$ of the most liquid sovereign bond portfolio would have generated an average annual excess return of $4 \%$.

This evidence suggests that the risk premium is larger for illiquid securities. The most liquid bonds are more sensitive to business-cycle risk, as captured by the excess returns of the foreign bond index, than the least liquid bonds. That is, the most liquid bonds carry larger betas than the least liquid bonds. At almost 50 basis points per month, this difference is substantial and statistically significant. The least liquid bonds are more exposed to the risk associated with changes in British interest rates, but this difference is not statistically different from zero. There are thus systematic differences between liquid and illiquid sovereign bonds attributable to their differential exposure to the excess returns of the foreign bond index.

As Table 3 reports, an unexpected decrease in liquidity reduces contemporaneous returns, which is consistent with economic theory. When there is a positive innovation in the bid-ask spread and market liquidity declines, sovereign bond prices fall and generating negative contemporaneous returns (Acharya and Pedersen 2005). The expected returns of these bonds 
therefore rise. The least liquid sovereign bonds are more sensitive to decreases in market liquidity than the most liquid bonds. On average, a one percentage point increase in the marketwide bid-ask spread reduces the returns on the least liquid bonds by $1.68 \%$ in a given month whereas a similar change in market liquidity reduces the returns on the most liquid bonds by 0.73\% in a given month. Both betas are statistically different from zero. The last column shows, however, that the difference between the two betas is not statistically significant at conventional levels.

Tables 4 and 5 show the results for equally weighted sovereign bond portfolios as test portfolios. They are similar to those reported in Tables 2 and 3, but at about 3.1\% per year the premium for holding illiquid sovereign bonds is somewhat smaller than that implied by the value-weighted portfolios. Again, the most liquid sovereign bonds are more exposed to businesscycle risk, as captured by the excess returns of the foreign bond index, and this difference is statistically significant. The difference between the exposure to innovations in British interest rates of the least liquid and the most liquid portfolios is smaller in magnitude than reported in Tables 2 and 3, and it remains statistically insignificant.

Table 5 indicates that including the unexpected change in market liquidity as a nontraded factor does not materially alter the results compared to those reported in Table 3, but the sensitivity of the least liquid portfolio to innovations in market liquidity is statistically different from the sensitivity of the most liquid portfolio to innovations in market liquidity. A one percentage point innovation in the market-wide bid-ask spread causes the returns on the least liquid sovereign bond portfolio to decline by $1.72 \%$ more than such an innovation causes the returns of the most liquid sovereign bond portfolio to decline. This finding is intuitive. Less liquid sovereign bonds are harder to trade during periods of market illiquidity and, consequently, such bonds tend to carry larger betas on unexpected changes in market liquidity.

The excess returns of the illiquid portfolio do not reflect the differential exposure of these bonds to the excess returns of the foreign bond market index. That the least liquid bonds are less sensitive to business-cycle risk than the most liquid bonds suggests that the larger excess returns these bonds earn is not compensation for bearing more aggregate risk. Instead these excess returns reflect compensation for bearing the risk associated with the least liquid portfolio’s sensitivity to market liquidity. 


\subsection{Are Smaller Bonds More Sensitive to Liquidity Innovations?}

Tables 6 and 7 report the regression results for the value-weighted test portfolios sorted by size. Table 6 shows that the small sovereign bond portfolio earns a 3.47\% premium relative to the large sovereign bond portfolio, after adjusting for business-cycle risk and interest-rate risk. Large sovereign bonds tend to be more exposed than small sovereign bonds to the risk associated with the excess returns on the foreign bond portfolio but less exposed to risk associated with changes in British interest rates. Both differences are statistically significant, but the difference in the betas associated with the excess returns of the foreign bond index is larger in magnitude. On average, a 1\% increase in the excess return of the foreign bond portfolio reduces the returns of the leveraged portfolio by $1.2 \%$ per month. By way of contrast, on average a $1 \%$ increase in the returns on the British consol index increases the returns of the leveraged portfolio by $0.23 \%$ in a given month.

Table 7 repeats the regressions from Table 6 but adds the portfolio $I M L_{t}$ as a traded factor. In every case except one, the estimated beta on the liquidity-mimicking portfolio is statistically different from zero. The largest and smallest sovereign bond portfolios carry different sensitivities to the liquidity-mimicking portfolio. The portfolio of the smallest sovereign bonds carries a loading that is 15 basis points larger than the loading associated with the portfolio of the largest sovereign bonds, suggesting that smaller sovereign bonds are more exposed to liquidity risk. Smaller sovereign bonds are also less sensitive to excess returns of the foreign bond index and more sensitive to changes in British interest rates. These findings make sense insofar as smaller sovereign bond issues are less liquid than larger sovereign bond issues and are consistent with the results in Tables 2-5.

Tables 8 and 9 repeat the regressions in Tables 6 and 7 but use equally weighted portfolios of sovereign bond returns sorted by size. Again, the portfolio of the smallest sovereign bonds is more sensitive to unexpected changes in market liquidity in the sovereign bond market, as captured by the liquidity-mimicking portfolio, although the difference between the sensitivities of the smallest and the largest sovereign bond portfolios to the liquidity-mimicking portfolio is not statistically different from zero. This finding indicates that the betas in this specification exhibit less dispersion than the betas in the specification with value-weighted

portfolios and suggests that there is larger estimation error associated with the smaller sovereign 
bond issues, which receive the same weight as the larger bond issues, and whose returns tend to be more volatile.

Taken together, these results suggest that the difference in returns between the least liquid portfolio and the most liquid portfolio can explain the differences in the variation of sovereign risk premia that are sorted by size. Smaller sovereign bonds are more exposed to liquidity risk than larger sovereign bonds, and this difference is both economically and statistically significant.

\subsection{Is Liquidity a Priced State Variable?}

Table 10 reports the efficient GMM estimates of the risk premia. The first column in the table (Unrestricted) reports the estimates for the risk premia from the model with all three risk factors. All of the estimated risk premia are statistically different from zero. A portfolio that had a beta of one with respect to the excess returns of the foreign bond portfolio and betas of zero with respect to the other two nondiversifiable risks would have earned about 3.8\% per year; a portfolio that had a beta of one with respect to the excess returns of the British consol and betas of zero with respect to the other two nondiversifiable risks would have earned about $4.1 \%$ per year; and a portfolio that had a beta of one with respect to the excess returns of the liquiditymimicking portfolio $I M L_{t}$ and betas of zero with respect to the other two nondiversifiable risks would have earned about $22.6 \%$ per year.

To get a better handle on the economic importance of these risk premia for the price of sovereign debt, one can inspect the estimated factor sensitivities from the $S M L$ portfolio that is long the smallest bonds and short the largest bonds. The component of a $S M L$ portfolio's expected return attributable to liquidity risk is given by the product of the estimated sensitivity to liquidity risk from Table 7 and the estimated liquidity premium from Table 10. The contribution of liquidity risk to the expected return of the $S M L$ portfolio is $3.38 \%$ per year $(0.15 \times 0.226)$. To put this value into perspective, the contribution of business-cycle risk is $4.48 \%$ per year $(-1.14 \times 0.0375)$ and that for interest-rate risk is $0.79 \%$ per year $(0.19 \times 0.0413)$. The negative contribution of business-cycle risk arises because the $S M L$ portfolio has a negative exposure to business-cycle risk. The estimated coefficient with respect to the foreign bond index on the small bond portfolio is smaller in size than the estimated 
coefficient with respect to the foreign bond index associated with the large bond portfolio. The contribution of liquidity risk to expected returns is comparable in magnitude to the contribution of business-cycle risk and larger than the contribution of interest-rate risk.

The second column (Restricted 1) shows the estimated risk premia for the model excluding the excess returns of the foreign bond portfolio. Both of the risk premia are economically and statistically significant. The estimated risk premium for the British consol is about 9.8\% per year; and the estimated risk premium for the liquidity-mimicking factor is about $14.2 \%$ per year. Although smaller in magnitude than the estimated liquidity premium in the unrestricted specification, the liquidity premium in this specification remains sizable. Again, this evidence indicates the importance of the liquidity premium in explaining sovereign risk premia. The results of the $D$-test suggest that one can reject the null hypothesis that the excess return of the British consol and the liquidity-mimicking factor by themselves provide a statistically adequate characterization of the sovereign risk premia.

The third column (Restricted 2) shows the estimated risk premia for the specification that excludes the excess returns of the British consol. The estimated risk premium for the foreign bond index is about 3.9\% per year and that for the liquidity premium is about $22.5 \%$ per year. The $D$-test rejects the null hypothesis that including the excess returns of the British consol in the unrestricted model does not statistically improve the performance of this model.

The fourth column (Restricted 3) reports the estimates from the specification excluding the liquidity-mimicking factor. The estimated risk premia for the foreign bond index and the British consol are both statistically significant. Importantly, the $D$-test rejects this specification in favor of the unrestricted model that includes the excess returns on the liquidity-mimicking factor. This finding therefore suggests that one should include liquidity-mimicking factor in the model to provide an adequate statistical characterization of sovereign risk premia.

Table 11 reports the GMM estimates of the risk premia for the equally weighted test portfolios. They are qualitatively similar to the results in Table 11, with one exception: The model Restricted 2 for the equally weighted test portfolios fails to reject the null hypothesis that the specification that includes only the foreign bond index and the liquidity-mimicking factor provides a statistically adequate characterization of these data.

All of the evidence points in the same direction. In each specification, the liquidity premium is statistically significant. Moreover, based on the estimates from the unrestricted 
model, the contribution of liquidity risk to the expected returns of the $S M L$ portfolio is economically meaningful. This finding is important because it shows that innovations in liquidity are a priced state variable, above and beyond business-cycle risk, as captured by the excess returns of the foreign bond index, and interest rate risk, as captured by the excess returns of the British consol. The main lesson to draw from these findings is that exposure to liquidity risk matters for pricing internationally traded sovereign debt. ${ }^{11}$

\section{Conclusion}

As recent developments in international debt markets illustrate, flights to liquidity are increasingly common. Despite the importance of uncovering the quantitative significance of liquidity risk in the price of sovereign debt, contemporary data are ill-suited to studying the relationship between liquidity risk and sovereign risk premia.

In contrast, the data used in this paper can shed light on this relationship. The late $19^{\text {th }}$ century provides the best available case for studying this question. This period was the last time that the sovereign debt of a diverse set of countries was actively traded on a centralized exchange for a period long enough to conduct asset-pricing tests. These data permit us to use a multifactor model to quantify the liquidity premium and to test the proposition that lenders value liquidity in the sovereign debt market, as recent anecdotal evidence suggests.

Empirical analysis of these data establishes three new results. First, sovereign bonds with wide bid-ask spreads earn about 3-4\% more per year than sovereign bonds with narrow bid-ask spreads. This premium for holding less liquid sovereign bonds tends to reflect the greater sensitivity of such bonds to unexpected changes in liquidity than more liquid sovereign bonds. Second, small sovereign bonds, as measured by market value, earn a premium relative to large sovereign bonds. This premium also reflects the greater sensitivity of small bonds to unexpected decreases in market liquidity. Third, the excess returns associated with a leveraged portfolio long the least liquid bonds and short the most liquid bonds is a state variable important for pricing sovereign debt. Cross-sectional differences in sovereign risk premia are linearly related to the sensitivities of returns to fluctuations in market liquidity, which is consistent with the

\footnotetext{
${ }^{11}$ These findings are consistent with evidence from the equity market. Decreases in market liquidity during financial crises tend to be correlated with breaks in financial parity conditions between otherwise identical equity shares (Pasquariello forthcoming). This evidence thus suggests that market liquidity is a nondiversifiable risk in the equity market.
} 
proposition that liquidity is a priced nondiversifiable risk. The liquidity premium's contribution to the sovereign risk premium is economically large and statistically significant: It is comparable in size to the contribution of business-cycle risk. This paper thus provides independent evidence on the quantitative importance of the liquidity premium that is consistent with recent anecdotal reports, which suggests that liquidity is a prominent and durable feature of the international market for sovereign debt. 


\section{References}

Acharya, V., Pedersen, L., 2005. Asset Pricing with Liquidity Risk. Journal of Financial Economics 77 (2), 375-410.

Andrews, D., Chen, H., 1994. Approximately Median-Unbiased Estimation of Autoregressive Models. Journal of Business and Economic Statistics 12 (2), 187-204.

Bank for International Settlements, 1999. Market Liquidity: Research Findings and Selected Policy Implications. BIS, Basel.

Barr, D., Priestley, R., 2004. Expected Returns, Risk, and the Integration of International Bond Markets. Journal of International Money and Finance 23 (1), 71-97.

Bordo, M. D., Murshid, A. P., 2002. Globalization and Changing Patterns in the International Transmission of Shocks in Financial Markets. Journal of International Money and Finance 25 (4), 655-674.

Chordia, T., Sarkar, A., Subrahmanyam, A., 2005. An Empirical Analysis of Stock and Bond Market Liquidity. Review of Financial Studies 18 (1), 85-129.

Chung, J., 2008. Flight to Liquidity Pushes Eurozone Bond Yields Apart. Financial Times, February 27, p. 27.

Connor, G., 1984. A Unified Beta Pricing Theory. Journal of Economic Theory 34 (1), 13-31.

Cumby, R., Pastine, T., 2001. Emerging Market Debt Measuring Credit Quality and Examining Relative Pricing. Journal of International Money and Finance 20 (5), 591-609.

Dittmar, R., Yuan, K., 2008. Do Sovereign Bonds Benefit Corporate Bonds in Emerging Markets? Review of Financial Studies 21 (5), 1983-2014. 
Fleming, M., 2002. Are Larger Treasury Issues More Liquid? Evidence from Bill Reopenings. Journal of Money, Credit, and Banking 34 (3), 707-735.

Glosten, L., Milgrom, P., 1985. Bid, Ask, and Transaction Prices in Specialist Market with Heterogeneously Informed Trader. Journal of Financial Economics 21 (1), 71-100.

Guha, K., Mackenzie, M., Tett, G., 2008. Panic Grips Credit Markets. Financial Times. September 18, p. 1.

Hansen, L., 1982. Large Sample Properties of Generalized Method of Moments Estimators. Econometrica 50 (4), 1029-1054.

Huberman, G., 1982. A Simple Approach to Arbitrage Pricing Theory. Journal of Economic Theory 28 (1), 183-191.

Ilmanen, A., 1995. Time-Varying Expected Returns in International Bonds. Journal of Finance 50 (2), 481-506.

Inoue, H., 1999. The Structure of Government Securities Markets in G10 Countries: Summary of Questionnaire Results. In: Market Liquidity: Research Findings and Selected Policy Implications. BIS, Basel.

Korajczyk, R., Sadka, R., 2008. Pricing the Commonality Across Alternative Measures of Liquidity. Journal of Financial Economics 87 (1), 45-72.

Mauro, P., Sussman, N., Yafeh, Y., 2002. Emerging Market Spreads: Then Versus Now. Quarterly Journal of Economics 117 (2), 695-733.

Michie, R., 2006. The Global Securities Market: A History. Oxford University Press, New York. 
Newey, W., West, K., 1987a. A Simple, Positive Definite, Heteroskedasticity and Autocorrelation Consistent Covariance Matrix. Econometrica 55 (3), 703-708.

Newey, W., West, K., 1987b. Hypothesis Testing with Efficient Method of Moments Estimation. International Economic Review 28 (3), 777-787.

Pasquariello, P., forthcoming. The Anatomy of Financial Crises: Evidence from the Emerging ADR Market. Journal of International Economics.

Ross, S., 1976. The Arbitrage Pricing Theory of Capital Asset Pricing. Journal of Economic Theory 13 (3), 341-360.

Stone, M., 1991. Are Sovereign Debt Secondary Market Returns Sensitive to Macroeconomic Fundamentals? Evidence from the Contemporary and Interwar Markets. Journal of International Money and Finance 10 (1), 100-122.

Suter, C., 1990. Schuldenzyklen in der dritten Welt: Kreditaufnahme, Zahlungskrisen und Schuldenregelungen peripherer Länder im Weltsystem von 1820 bis 1986. Anton Hain, Frankfurt.

Takagi, S., 1987. Transaction Costs and the Term Structure of Interest Rates in the OTC Bond Market in Japan. Journal of Money, Credit, and Banking 19 (4), 515-527.

Taylor, A. M., 2002. A Century of Current Account Dynamics. Journal of International Money and Finance 21 (6), 725-748.

Uribe, M., Yue, V., 2006. Country Spreads and Emerging Countries: Who Drives Whom? Journal of International Economics 69 (1), 6-36. 
Table 1. Time-Series Features of Bond Market Liquidity

\begin{tabular}{|c|c|c|}
\hline & $\begin{array}{c}\text { Level } \\
\text { (percent) }\end{array}$ & $\begin{array}{l}\text { Change } \\
\text { (percentage points) }\end{array}$ \\
\hline Mean & 2.38 & 0.00 \\
\hline ( $p$-value) & $(0.00)$ & $(0.48)$ \\
\hline Mean Abs. Dev. & 2.38 & 0.14 \\
\hline Min. & 1.48 & -1.16 \\
\hline Max. & 4.46 & 1.56 \\
\hline Persistence & 0.93 & 0.15 \\
\hline \multicolumn{3}{|c|}{$\begin{array}{l}\text { Notes: The sample is 1871.1-1907.12 (482 observations). The } p \text { - } \\
\text { values of the test for a zero mean are based on heteroskedasticity } \\
\text { and autocorrelation robust standard errors (Newey and West } \\
\text { 1987a). The measure of persistence is the sum of the } \\
\text { autoregressive coefficients (Andrews and Chen 1994). The } \\
\text { autoregressive lag order is determined using the AIC with an } \\
\text { upper bound of } 26 \text { lags ( } 2 \text { calendar years). }\end{array}$} \\
\hline
\end{tabular}


Table 2. Value-Weighted Sovereign Bond Portfolios Sorted by Bid-Ask Spread

Dependent Variable: $r_{i t}-r_{f t}$

\begin{tabular}{|c|c|c|c|c|c|c|c|c|c|c|c|}
\hline & Liquid & 2 & 3 & 4 & 5 & 6 & 7 & 8 & 9 & Illiquid & $I M L$ \\
\hline Annualized $\bar{r}_{i}-\bar{r}_{f}$ & 2.48 & 3.13 & 2.88 & 2.50 & 2.60 & 1.90 & 2.49 & 4.58 & 3.50 & 5.10 & 2.62 \\
\hline \multirow[t]{2}{*}{ Annualized $\hat{a}_{i}$} & 0.79 & 2.74 & 2.22 & 2.16 & 2.39 & 1.51 & 1.93 & 4.08 & 3.64 & 4.79 & 4.00 \\
\hline & $(0.23)$ & $(0.00)$ & $(0.01)$ & $(0.00)$ & $(0.00)$ & $(0.00)$ & $(0.00)$ & $(0.00)$ & $(0.00)$ & $(0.02)$ & $(0.03)$ \\
\hline \multirow[t]{2}{*}{$\hat{b}_{M}$} & 0.56 & 0.12 & 0.21 & 0.10 & 0.06 & 0.12 & 0.17 & 0.16 & -0.06 & 0.09 & -0.47 \\
\hline & $(0.00)$ & $(0.00)$ & $(0.09)$ & $(0.24)$ & $(0.28)$ & $(0.20)$ & $(0.14)$ & $(0.20)$ & $(0.41)$ & $(0.40)$ & $(0.05)$ \\
\hline \multirow[t]{2}{*}{$\hat{b}_{C}$} & 0.14 & 0.41 & 0.42 & 0.33 & 0.28 & 0.31 & 0.45 & 0.33 & 0.53 & 0.40 & 0.26 \\
\hline & $(0.05)$ & $(0.00)$ & $(0.00)$ & $(0.00)$ & $(0.00)$ & $(0.00)$ & $(0.00)$ & $(0.00)$ & $(0.00)$ & $(0.03)$ & $(0.16)$ \\
\hline $\bar{R}^{2}$ & 0.34 & 0.11 & 0.16 & 0.10 & 0.08 & 0.11 & 0.18 & 0.08 & 0.08 & 0.03 & 0.09 \\
\hline
\end{tabular}


Table 3. Value-Weighted Sovereign Bond Portfolios Sorted by Bid-Ask Spread

Dependent Variable: $r_{i t}-r_{f t}$

\begin{tabular}{|c|c|c|c|c|c|c|c|c|c|c|c|}
\hline & Liquid & 2 & 3 & 4 & 5 & 6 & 7 & 8 & 9 & Illiquid & $I M L$ \\
\hline Annualized $\bar{r}_{i}-\bar{r}_{f}$ & 2.48 & 3.13 & 2.88 & 2.50 & 2.60 & 1.90 & 2.49 & 4.58 & 3.50 & 5.10 & 2.62 \\
\hline \multirow[t]{2}{*}{ Annualized $\hat{a}_{i}$} & 0.77 & 2.74 & 2.22 & 2.14 & 2.38 & 1.51 & 1.92 & 4.07 & 3.63 & 4.76 & 3.98 \\
\hline & $(0.23)$ & $(0.00)$ & $(0.01)$ & $(0.00)$ & $(0.00)$ & $(0.01)$ & $(0.00)$ & $(0.00)$ & $(0.00)$ & $(0.00)$ & $(0.03)$ \\
\hline \multirow[t]{2}{*}{$\hat{b}_{M}$} & 0.57 & 0.12 & 0.21 & 0.11 & 0.07 & 0.12 & 0.18 & 0.16 & -0.06 & 0.10 & -0.47 \\
\hline & $(0.00)$ & $(0.28)$ & $(0.08)$ & $(0.22)$ & $(0.26)$ & $(0.19)$ & $(0.13)$ & $(0.19)$ & $(0.41)$ & $(0.38)$ & $(0.05)$ \\
\hline \multirow[t]{2}{*}{$\hat{b}_{C}$} & 0.14 & 0.41 & 0.42 & 0.33 & 0.28 & 0.31 & 0.45 & 0.33 & 0.53 & 0.40 & 0.26 \\
\hline & $(0.05)$ & $(0.00)$ & $(0.00)$ & $(0.00)$ & $(0.00)$ & $(0.00)$ & $(0.00)$ & $(0.00)$ & $(0.00)$ & $(0.03)$ & $(0.16)$ \\
\hline \multirow[t]{2}{*}{$\hat{b}_{L}$} & -0.73 & -0.10 & -0.09 & -0.84 & -0.45 & -0.26 & -0.49 & -0.42 & -0.57 & -1.68 & -0.95 \\
\hline & $(0.08)$ & $(0.38)$ & $(0.42)$ & $(0.07)$ & $(0.07)$ & $(0.23)$ & $(0.21)$ & $(0.28)$ & $(0.16)$ & $(0.07)$ & $(0.14)$ \\
\hline $\bar{R}^{2}$ & 0.34 & 0.11 & 0.16 & 0.11 & 0.08 & 0.11 & 0.18 & 0.09 & 0.08 & 0.05 & 0.10 \\
\hline
\end{tabular}

Notes: The regression is $r_{i t}-r_{f t}=a_{i}+b_{M i}\left(r_{M t}-r_{f t}\right)+b_{C i}\left(r_{C t}-r_{f t}\right)+b_{L i} \Delta L_{t}+\varepsilon_{i t}$ and the estimation period is 1871.11907.12 (482 observations). IML denotes the leveraged portfolio that is long $£ 1$ of the most illiquid portfolio and short $£ 1$ of the most liquid portfolio. The $p$-values in parentheses are based on the heteroskedasticity and autocorrelation robust standard errors (Newey and West 1987a) and the asymptotic critical values. 
Table 4. Equally Weighted Sovereign Bond Portfolios Sorted by Bid-Ask Spread

Dependent Variable: $r_{i t}-r_{f t}$

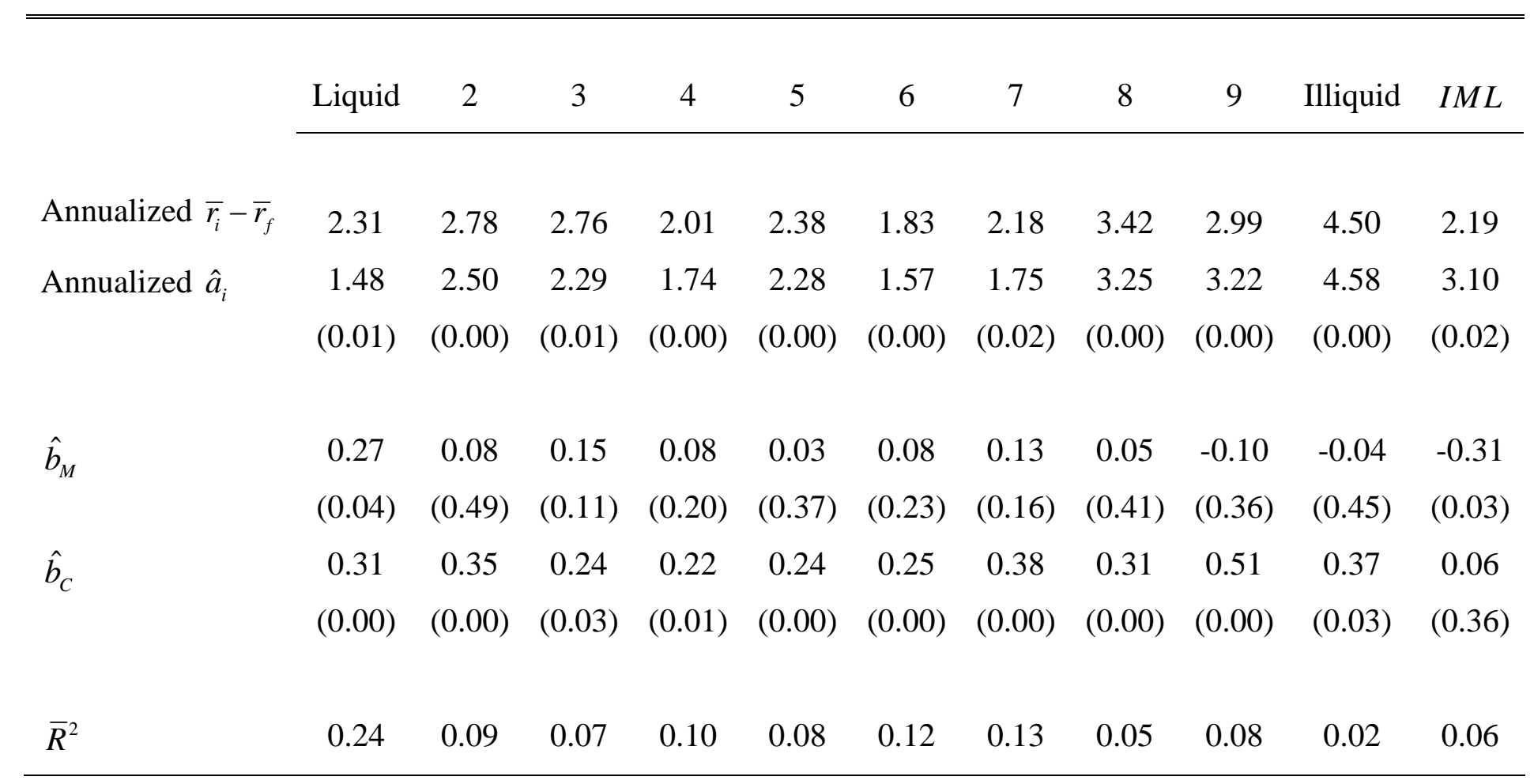

Notes: The regression is $r_{i t}-r_{f t}=a_{i}+b_{M i}\left(r_{M t}-r_{f t}\right)+b_{C i}\left(r_{C t}-r_{f t}\right)+\varepsilon_{i t} . I M L$ denotes the leveraged portfolio that is long $£ 1$ of the most illiquid portfolio and short $£ 1$ of the most liquid portfolio. The $p$-values in parentheses are based on the heteroskedasticity and autocorrelation robust standard errors (Newey and West 1987a) and the asymptotic critical values. 
Table 5. Equally Weighted Sovereign Bond Portfolios Sorted by Bid-Ask Spread

Dependent Variable: $r_{i t}-r_{f t}$

\begin{tabular}{|c|c|c|c|c|c|c|c|c|c|c|c|}
\hline & Liquid & 2 & 3 & 4 & 5 & 6 & 7 & 8 & 9 & Illiquid & $I M L$ \\
\hline Annualized $\overline{r_{i}}-\bar{r}_{f}$ & 2.31 & 2.78 & 2.76 & 2.01 & 2.38 & 1.83 & 2.18 & 3.42 & 2.99 & 4.50 & 2.19 \\
\hline \multirow[t]{2}{*}{ Annualized $\hat{a}_{i}$} & 1.48 & 2.49 & 2.28 & 1.73 & 2.28 & 1.56 & 1.73 & 3.23 & 3.20 & 4.54 & 3.07 \\
\hline & $(0.01)$ & $(0.00)$ & $(0.01)$ & $(0.00)$ & $(0.00)$ & $(0.00)$ & $(0.02)$ & $(0.00)$ & $(0.00)$ & $(0.00)$ & $(0.02)$ \\
\hline \multirow[t]{2}{*}{$\hat{b}_{M}$} & 0.27 & 0.09 & 0.16 & 0.09 & 0.03 & 0.08 & 0.14 & 0.06 & -0.08 & -0.02 & -0.29 \\
\hline & $(0.04)$ & $(0.31)$ & $(0.09)$ & $(0.18)$ & $(0.35)$ & $(0.22)$ & $(0.14)$ & $(0.39)$ & $(0.37)$ & $(0.47)$ & $(0.03)$ \\
\hline \multirow[t]{2}{*}{$\hat{b}_{C}$} & 0.31 & 0.35 & 0.23 & 0.22 & 0.24 & 0.325 & 0.38 & 0.31 & 0.51 & 0.37 & 0.06 \\
\hline & $(0.00)$ & $(0.00)$ & $(0.02)$ & $(0.00)$ & $(0.00)$ & $(0.00)$ & $(0.00)$ & $(0.00)$ & $(0.00)$ & $(0.02)$ & (0.37) \\
\hline \multirow[t]{2}{*}{$\hat{b}_{L}$} & -0.21 & -0.13 & -0.78 & -0.59 & -0.34 & -0.31 & -0.65 & -0.75 & -1.14 & -1.94 & -1.72 \\
\hline & $(0.25)$ & $(0.32)$ & $(0.04)$ & $(0.14)$ & $(0.06)$ & $(0.16)$ & $(0.20)$ & $(0.11)$ & $(0.01)$ & $(0.05)$ & $(0.05)$ \\
\hline $\bar{R}^{2}$ & 0.24 & 0.09 & 0.08 & 0.07 & 0.08 & 0.11 & 0.14 & 0.09 & 0.09 & 0.05 & 0.08 \\
\hline
\end{tabular}

Notes: The regression is $r_{i t}-r_{f t}=a_{i}+b_{M i}\left(r_{M t}-r_{f t}\right)+b_{C i}\left(r_{C t}-r_{f t}\right)+b_{L i} \Delta L_{t}+\varepsilon_{i t} . I M L$ denotes the leveraged portfolio that is long $£ 1$ of the most illiquid portfolio and short $£ 1$ of the most liquid portfolio. The $p$-values in parentheses are based on the heteroskedasticity and autocorrelation robust standard errors (Newey and West 1987a) and the asymptotic critical values. 
Table 6. Value-Weighted Sovereign Bond Portfolios Sorted by Size

Dependent Variable: $r_{i t}-r_{f t}$

\begin{tabular}{lcccccccccccc} 
& Small & 2 & 3 & 4 & 5 & 6 & 7 & 8 & 9 & Large & $S M L$ \\
\cline { 2 - 11 } & & & & & & & & & & & \\
Annualized $\bar{r}_{i}-\bar{r}_{f}$ & 4.05 & 2.98 & 3.84 & 3.94 & 4.58 & 3.26 & 3.97 & 2.52 & 3.44 & 4.16 & -0.11 \\
Annualized $\hat{a}_{i}$ & 3.83 & 3.45 & 4.03 & 3.89 & 4.31 & 3.11 & 3.42 & 2.15 & 2.77 & 0.37 & 3.47 & \\
& $(0.00)$ & $(0.00)$ & $(0.00)$ & $(0.00)$ & $(0.00)$ & $(0.00)$ & $(0.00)$ & $(0.00)$ & $(0.00)$ & $(0.15)$ & $(0.00)$ \\
& & & & & & & & & & & \\
$\hat{b}_{M}$ & 0.07 & -0.17 & -0.07 & 0.01 & 0.08 & 0.04 & 0.18 & 0.11 & 0.21 & 1.28 & -1.21 \\
$\hat{b}_{M}$ & $(0.06)$ & $(0.15)$ & $(0.34)$ & $(0.48)$ & $(0.29)$ & $(0.28)$ & $(0.20)$ & $(0.22)$ & $(0.17)$ & $(0.00)$ & $(0.00)$ \\
& 0.15 & 0.37 & 0.22 & 0.30 & 0.27 & 0.38 & 0.34 & 0.38 & 0.43 & -0.08 & 0.23 \\
$\bar{R}^{2}$ & $(0.00)$ & $(0.00)$ & $(0.03)$ & $(0.00)$ & $(0.00)$ & $(0.00)$ & $(0.01)$ & $(0.00)$ & $(0.00)$ & $(0.00)$ & $(0.00)$ \\
& & & & & & & & & & & 0.96 & 0.74
\end{tabular}

Notes: The regression is $r_{i t}-r_{f t}=a_{i}+b_{M i}\left(r_{M t}-r_{f t}\right)+b_{C i}\left(r_{C t}-r_{f t}\right)+\varepsilon_{i t} . S M L$ denotes the leveraged portfolio that is long $£ 1$ of the smallest portfolio and short $£ 1$ of the largest portfolio. The $p$-values in parentheses are based on the heteroskedasticity and autocorrelation robust standard errors (Newey and West 1987a) and the asymptotic critical values. 
Table 7. Value-Weighted Sovereign Bond Portfolios Sorted by Size

Dependent Variable: $r_{i t}-r_{f t}$

\begin{tabular}{lccccccccccc} 
& Small & 2 & 3 & 4 & 5 & 6 & 7 & 8 & 9 & Large & $S M L$ \\
\cline { 2 - 10 } & & & & & & & & & & & \\
Annualized $\bar{r}_{i}-\bar{r}_{f}$ & 4.05 & 2.98 & 3.84 & 3.94 & 4.58 & 3.26 & 3.97 & 2.52 & 3.44 & 4.16 & -0.11 \\
Annualized $\hat{a}_{i}$ & 3.31 & 2.85 & 2.97 & 3.89 & 3.59 & 2.45 & 2.93 & 1.80 & 2.27 & 0.43 & 2.88 \\
& $(0.00)$ & $(0.00)$ & $(0.00)$ & $(0.00)$ & $(0.00)$ & $(0.00)$ & $(0.00)$ & $(0.00)$ & $(0.00)$ & $(0.08)$ & $(0.00)$ \\
& & & & & & & & & & & \\
$\hat{b}_{M}$ & 0.13 & -0.10 & 0.05 & 0.04 & 0.17 & 0.12 & 0.23 & 0.15 & 0.27 & 1.27 & -1.14 \\
& $(0.02)$ & $(0.25)$ & $(0.31)$ & $(0.48)$ & $(0.08)$ & $(0.11)$ & $(0.09)$ & $(0.11)$ & $(0.08)$ & $(0.00)$ & $(0.00)$ \\
$\hat{b}_{C}$ & 0.11 & 0.33 & 0.15 & 0.28 & 0.22 & 0.33 & 0.31 & 0.36 & 0.40 & -0.07 & 0.19 \\
& $(0.01)$ & $(0.00)$ & $(0.04)$ & $(0.00)$ & $(0.00)$ & $(0.00)$ & $(0.00)$ & $(0.00)$ & $(0.00)$ & $(0.01)$ & $(0.00)$ \\
$\hat{b}_{L}$ & 0.13 & 0.15 & 0.26 & 0.06 & 0.18 & 0.16 & 0.12 & 0.09 & 0.13 & -0.02 & 0.15 \\
& $(0.05)$ & $(0.00)$ & $(0.00)$ & $(0.00)$ & $(0.00)$ & $(0.00)$ & $(0.00)$ & $(0.00)$ & $(0.00)$ & $(0.31)$ & $(0.05)$ \\
$\bar{R}^{2}$ & & & & & & & & & & & 0.96 \\
\hline
\end{tabular}

Notes: The regression is $r_{i t}-r_{f t}=a_{i}+b_{M i}\left(r_{M t}-r_{f t}\right)+b_{C i}\left(r_{C t}-r_{f t}\right)+b_{L i} I M L_{t}+\varepsilon_{i t} . S M L$ denotes the leveraged portfolio that is long $£ 1$ of the smallest portfolio and short $£ 1$ of the largest portfolio. The $p$-values in parentheses are based on the heteroskedasticity and autocorrelation robust standard errors (Newey and West 1987a) and the asymptotic critical values. 
Table 8. Equally Weighted Sovereign Bond Portfolios Sorted by Size

Dependent Variable: $r_{i t}-r_{f t}$

\begin{tabular}{lcccccccccccc} 
& Small & 2 & 3 & 4 & 5 & 6 & 7 & 8 & 9 & Large & $S M L$ \\
\cline { 2 - 11 } & & & & & & & & & & & \\
Annualized $\bar{r}_{i}-\bar{r}_{f}$ & 3.72 & 2.41 & 3.00 & 3.29 & 3.60 & 2.39 & 3.10 & 2.11 & 3.07 & 3.04 & 0.68 \\
Annualized $\hat{a}_{i}$ & 3.56 & 3.01 & 3.20 & 3.24 & 3.33 & 2.23 & 2.53 & 1.73 & 2.43 & 1.45 & 2.11 \\
& $(0.00)$ & $(0.00)$ & $(0.00)$ & $(0.00)$ & $(0.00)$ & $(0.00)$ & $(0.01)$ & $(0.00)$ & $(0.00)$ & $(0.00)$ & $(0.01)$ \\
& & & & & & & & & & & \\
$\hat{b}_{M}$ & 0.05 & -0.22 & -0.08 & 0.01 & 0.08 & 0.04 & 0.18 & 0.11 & 0.20 & 0.53 & -0.47 \\
$\hat{b}_{C}$ & $(0.09)$ & $(0.11)$ & $(0.32)$ & $(0.48)$ & $(0.29)$ & $(0.38)$ & $(0.19)$ & $(0.23)$ & $(0.17)$ & $(0.00)$ & $(0.00)$ \\
& 0.13 & 0.37 & 0.23 & 0.29 & 0.24 & 0.39 & 0.34 & 0.37 & 0.43 & 0.28 & -0.15 \\
& $(0.00)$ & $(0.00)$ & $(0.02)$ & $(0.00)$ & $(0.00)$ & $(0.00)$ & $(0.01)$ & $(0.00)$ & $(0.00)$ & $(0.00)$ & $(0.01)$ \\
$\bar{R}^{2}$ & & & & & & & & & & & 0.15
\end{tabular}

Notes: The regression is $r_{i t}-r_{f t}=a_{i}+b_{M i}\left(r_{M t}-r_{f t}\right)+b_{C i}\left(r_{C t}-r_{f t}\right)+\varepsilon_{i t} . S M L$ denotes the leveraged portfolio that is long $£ 1$ of the smallest portfolio and short $£ 1$ of the largest portfolio. The $p$-values in parentheses are based on the heteroskedasticity and autocorrelation robust standard errors (Newey and West 1987a) and the asymptotic critical values. 
Table 9. Equally Weighted Sovereign Bond Portfolios Sorted by Size

Dependent Variable: $r_{i t}-r_{f t}$

\begin{tabular}{lccccccccccc} 
& Small & 2 & 3 & 4 & 5 & 6 & 7 & 8 & 9 & Large & $S M L$ \\
\cline { 2 - 10 } & & & & & & & & & & & \\
Annualized $\bar{r}_{i}-\bar{r}_{f}$ & 3.72 & 2.41 & 3.00 & 3.29 & 3.60 & 2.39 & 3.10 & 2.11 & 3.07 & 3.04 & 0.68 \\
Annualized $\hat{a}_{i}$ & 3.19 & 2.39 & 2.24 & 2.98 & 2.56 & 1.60 & 2.03 & 1.38 & 1.92 & 1.35 & 1.84 \\
& $(0.00)$ & $(0.00)$ & $(0.00)$ & $(0.00)$ & $(0.00)$ & $(0.03)$ & $(0.02)$ & $(0.01)$ & $(0.00)$ & $(0.00)$ & $(0.01)$ \\
& & & & & & & & & & & \\
$\hat{b}_{M}$ & 0.09 & -0.14 & 0.04 & 0.04 & 0.17 & 0.11 & 0.24 & 0.16 & 0.26 & 0.54 & -0.44 \\
& $(0.01)$ & $(0.18)$ & $(0.37)$ & $(0.37)$ & $(0.08)$ & $(0.10)$ & $(0.09)$ & $(0.11)$ & $(0.08)$ & $(0.00)$ & $(0.00)$ \\
$\hat{b}_{C}$ & 0.10 & 0.33 & 0.17 & 0.27 & 0.19 & 0.35 & 0.31 & 0.34 & 0.40 & 0.28 & -0.17 \\
& $(0.00)$ & $(0.00)$ & $(0.02)$ & $(0.00)$ & $(0.01)$ & $(0.00)$ & $(0.00)$ & $(0.00)$ & $(0.00)$ & $(0.00)$ & $(0.01)$ \\
$\hat{b}_{L}$ & 0.09 & 0.16 & 0.24 & 0.07 & 0.19 & 0.16 & 0.13 & 0.09 & 0.13 & 0.03 & 0.07 \\
& $(0.05)$ & $(0.00)$ & $(0.00)$ & $(0.00)$ & $(0.00)$ & $(0.00)$ & $(0.00)$ & $(0.00)$ & $(0.00)$ & $(0.27)$ & $(0.16)$ \\
& & & & & & & & & & & \\
$\bar{R}^{2}$ & 0.11 & 0.22 & 0.23 & 0.08 & 0.14 & 0.20 & 0.12 & 0.21 & 0.25 & 0.67 & 0.43 \\
\hline
\end{tabular}

Notes: The regression is $r_{i t}-r_{f t}=a_{i}+b_{M i}\left(r_{M t}-r_{f t}\right)+b_{C i}\left(r_{C t}-r_{f t}\right)+b_{L i} I M L_{t}+\varepsilon_{i t} . S M L$ denotes the leveraged portfolio that is long $£ 1$ of the smallest portfolio and short $£ 1$ of the largest portfolio. The $p$-values in parentheses are based on the heteroskedasticity and autocorrelation robust standard errors (Newey and West 1987a) and the asymptotic critical values. 
Table 10. Annualized Risk Premia for Value-Weighted Sovereign Bond Portfolios

Dependent Variable: $r_{i}-r_{f}$

\begin{tabular}{lcccc}
\hline & Unrestricted & Restricted 1 & Restricted 2 & Restricted 3 \\
\cline { 2 - 5 }$\hat{\lambda}_{B}$ & 3.75 & & 3.88 & 3.89 \\
\multirow{2}{*}{$\hat{\lambda}_{C}$} & $(0.01)$ & & $(0.01)$ & $(0.00)$ \\
& 4.13 & 9.79 & & 9.82 \\
$\hat{\lambda}_{L}$ & $(0.01)$ & $(0.00)$ & & $(0.01)$ \\
& 22.56 & 14.23 & 22.45 & \\
$J_{T}$-test & $(0.00)$ & $(0.02)$ & $(0.00)$ & \\
& 12.74 & 13.90 & 12.36 & 16.92 \\
$D$-test & $(0.08)$ & $(0.08)$ & $(0.14)$ & $(0.03)$ \\
& & 22.83 & 4.87 & 24.26 \\
Reject $H_{0}$ ? & & $(0.00)$ & $(0.03)$ & $(0.00)$ \\
\hline
\end{tabular}

Notes: The estimates are based on equation (8) in the text. $\hat{\lambda}_{B}$ is the risk premium associated with the foreign bond

index; $\hat{\lambda}_{C}$ is the risk premium associated with the British consol index; $\hat{\lambda}_{L}$ is the risk premium associated with the liquidity-mimicking portfolio. $J_{T}$-test is the Hansen (1982) test of the overidentifying restrictions. The null hypothesis is that the moment conditions are all satisfied. $D$-test is the Newey-West (1987b) model specification test. The null hypothesis is that including the additional variables in the unrestricted model does not improve the performance of the restricted model. The estimates in the restricted model are based on optimal weighting matrix from the unrestricted model. The $p$-values in parentheses are based on the heteroskedasticity and autocorrelation robust standard errors. 
Table 11. Risk Premia for Equally Weighted Sovereign Bond Portfolios

Dependent Variable: $r_{i}-r_{f}$

\begin{tabular}{lcccc}
\hline \hline & Unrestricted & Restricted 1 & Restricted 2 & Restricted 3 \\
\cline { 2 - 5 }$\hat{\lambda}_{B}$ & 6.47 & & 7.14 & 2.36 \\
$\hat{\lambda}_{C}$ & $(0.00)$ & & $(0.00)$ & $(0.12)$ \\
& 1.97 & 8.56 & & 9.24 \\
$\hat{\lambda}_{L}$ & $(0.13)$ & $(0.00)$ & & $(0.00)$ \\
& 23.28 & 21.05 & 21.26 & \\
$J_{T}$-test & $(0.00)$ & $(0.00)$ & $(0.00)$ & 20.24 \\
& 14.28 & 17.99 & 13.50 & $(0.01)$ \\
& $(0.05)$ & $(0.02)$ & $(0.10)$ & 28.50 \\
$D$-test & & & & $(0.00)$ \\
& & 26.60 & 0.18 & Yes \\
\hline Reject $H_{0}$ ? & & $(0.00)$ & $(0.67)$ & No \\
\hline Notes: See Table 10.0 & & Yes & &
\end{tabular}


Figure 1. Market Liquidity in the London Sovereign Bond Market, 1871.1-1907.12
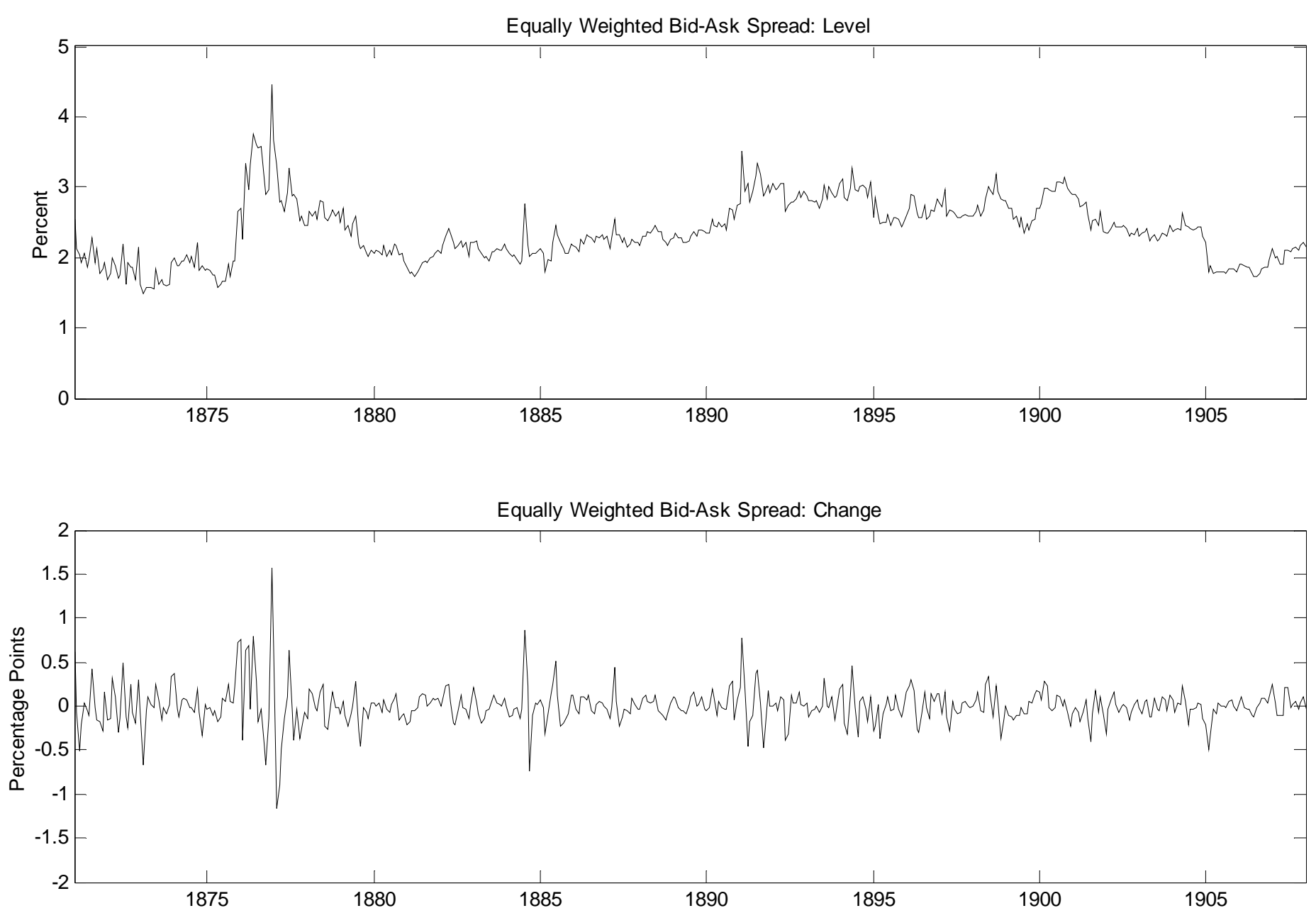

Notes: The change in the market-wide bid-ask spread is defined in equation (3) of the text. 
Figure 2. Market Liquidity and Major Defaults, 1871.1-1907.12

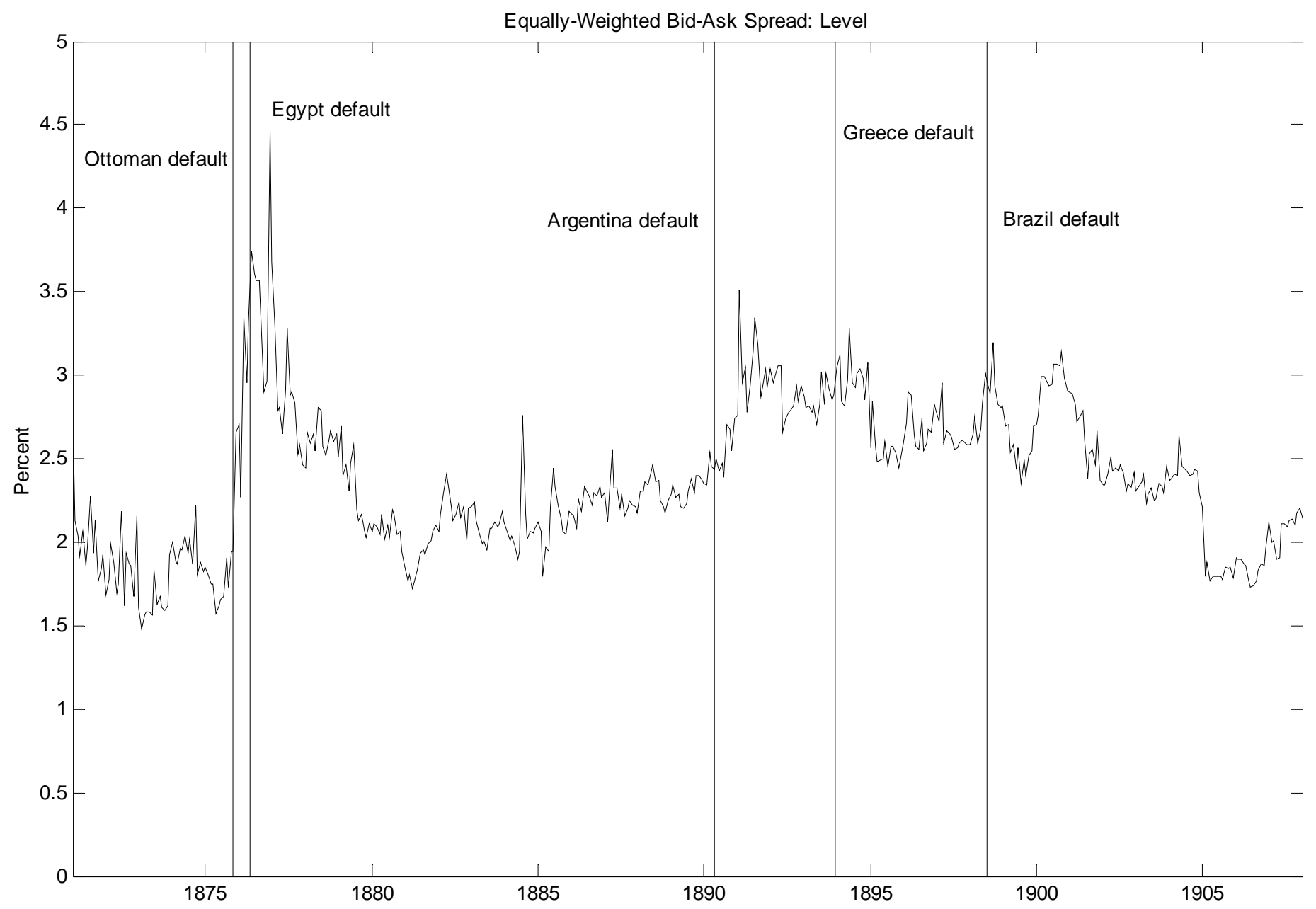


Figure 3. Changes in Market Liquidity and Major Defaults, 1871.1-1907.12

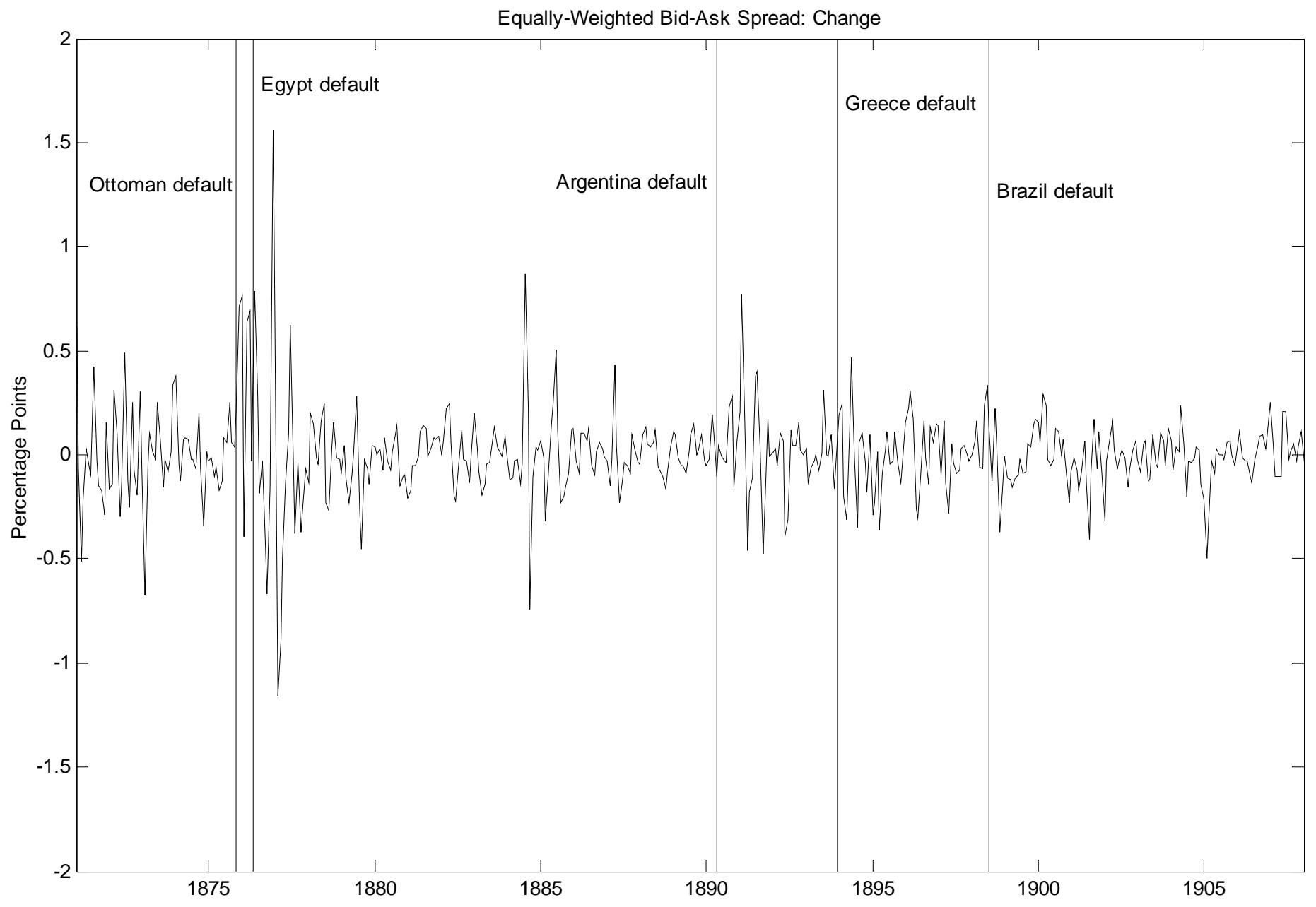




\section{Appendix 1. Sovereign Bond Price Data}

The time series of realized holding-period returns for each of the sovereign bonds are corrected for sovereign defaults. The dates of the defaults are provided by Suter (1990). Although the sovereign bonds in default were not actively traded, it was common for the underwriting firms to keep these bonds on the books. The prices of these sovereign bonds were quoted in the Money Market Review and the Economist, even though they ceased paying coupons and were not actively traded on the exchange. Depending on how negotiations between the debtor country and its creditors proceeded, these bonds could remain on the underwriters' books for years. These sovereign bonds pose a challenge because they tend to have very wide bid-ask spreads and very low returns, biasing the returns of the most illiquid portfolio downwards and the returns of the most liquid portfolio upwards. To address this problem, the data set excludes all of the sovereign bonds trading below $£ 40$ or $40 \%$ of par.

\section{Sovereign Bond Data}

The countries included in the sovereign-bond dataset are Argentina; Australia; Austria-Hungary; Belgium; Brazil; British Guiana; Bulgaria; Canada; Ceylon; Chile; China; Colombia; Costa Rica; Denmark; Ecuador; Egypt; France; Germany; Greece; Guatemala; Hawaii; Honduras; Hong Kong; Italy; Jamaica; Japan; Liberia; Mauritius; Mexico; Netherlands; New Zealand; Nicaragua; Norway; Orange Free State; Paraguay; Peru; Portugal; Russia; Saint Lucia; Santo

Domingo; South Africa; Spain; Straits Settlements; Sweden; Trinidad; Turkey; United States; Uruguay; and Venezuela.

The British colonies comprise a subset of the countries in this sample. They are Australia; British Guiana; Canada; Ceylon; Hong Kong; Jamaica; Mauritius; New Zealand; Saint Lucia; South Africa; and Trinidad. 